\title{
GAMBARAN DIAGNOSA DAN TATALAKSANA PASIEN DENGUE HEMORHAGIC FEVER (DHF) YANG RAWAT INAP DI RSU ROYAL PRIMA MEDAN TAHUN 2019
}

\author{
Bayu Ramazata ${ }^{1}$ Nerseri Barus ${ }^{2}$ \\ 1,2Program Studi Pendidikan Dokter, Fakultas Kedokteran, Universitas Prima Indonesia \\ bayuramazata98@gmail.com
}

\begin{abstract}
Abstrak
Dengue Hemorrhagic Fever (DHF) disebabkan infeksius agennya merupakan Virus dengue dari genus Flavirus, dan family Flaviviridae yang disebarkan dari gigitan nyamuk betina Aedes aegypti dan Aedes albopictus. Tujuan dari penelitian ini Untuk mengetahui Gambaran Diagnosa dan Tatalaksana Pasien DHF Rawat Inap di RSU Royal Prima Medan Tahun 2019. Peneliitian ini dilakukan dengan metode design studi kasus yang bersifat deskriptif dan retrospektif, besar sampel 100 data rekam medis pasien diambil secara purposive sampling, yaitu rekam medis yang paling lengkap datanya dan dianalisa dengan deskriptif statistik. Pada hasil ditemukan umur termuda yaitu 4 tahun dan umur tertua 59 tahun, dengan jumlah laki - laki sebanyak 56 orang dan perempuan sebanyak 44 orang. Keluhan yang paling banyak ditemukan yaitu demam tinggi 95 orang dan tatalaksana kombinasi farmakologi terbanyak paracetamol + anti emetic + proton pump inhibitor + vitamin B-complex (60\%) dan terapi non farmakologi yang dilakukan adalah terapi cairan ringer laktat. Kesimpulan yang didapatkan ialah distribusi terjadinya penyakit DHF lebih tinggi pada laki-laki (56\%) dari pada perempuan (44\%) dan keluhan terbanyak ialah demam tinggi (95\%) dan tatalaksana kombinasi paling banyak digunakan ialah paracetamol + anti emetic + proton pump inhibitor + vitamin B-complex (60\%) serta pemberian cairan ringer laktat (100\%).
\end{abstract}

Kata Kunci : Dengue Hemorrhagic Fever, Diagnosa dan Tatalaksana, RSU Royal Prima Medan

\begin{abstract}
Dengue Hemorrhagic Fever (DHF) which causes infectious agents is the dengue virus of the genus Flavirus, and the family Flaviviridae which transmitted from the bite of female mosquitoes Aedes aegypti and Aedes albopictus. The purpose of this research is to study the description of diagnosis and management of DHF inpatients at Royal Prima General Hospital in Medan in 2019. This research conducted with a case study design method that researched and retrospectively, a sample size of 100 medical records taken using purposive sampling, namely the most medical records complete data and analyzed with descriptive statistics. The results show that the youngest is four years old and 59 years old, with 56 men and 44 women. The most common complaints were high fever 95 people, and the most pharmacological combination of paracetamol + antiemetic + proton pump inhibitors + vitamin B-complex (60\%) and non-pharmacological therapy performed was lactate ring fluid therapy. The conclusion obtained from the distribution of DHF disease is higher in men (56\%) than in women (44\%), and the most common complaint is high fever (95\%). The most widely used combination is paracetamol + anti-emetic + proton pump inhibitor + Vitamin B-complex (60\%) and administration of lactated ringer fluid (100\%).
\end{abstract}

Keywords: Dengue Hemorrhagic Fever, Diagnosis and Manegement, Royal Prima Medan Hospital 
Jurnal Ilmiah Mahasiswa Kesehatan Masyarakat Vol. 5/No. 3/Juli 2020; Issn: 2502-731X

\section{PENDAHULUAN}

Dengue Hemorrhagic Fever (DHF) atau Demam Berdarah Dengue (DBD) merupakan suatu penyakit yang disebabkan infeksius agennya adalah Virus dengue dari genus Flavirus, dan golongan Flaviviridae yang disebarkan dari gigitan nyamuk Aedes aegypti dan Aedes albopictus. Iklim tropis dan suhu yang lembab merupakan habitat tempat tinggal dari nyamuk yang mempunyai tubuh hitam dengan belang putih dikakinya ${ }^{(1),(2)}$.

DHF dapat menyerang semua kelompok umur dan mempunyai gejala klinis berupa demam tinggi terus-menerus selama 2 hingga 7 hari dengan suhu $>38^{\circ} \mathrm{C}$, petekie (ruam-ruam merah pada kulit) , nyeri dibagian perut, mual-muntah, diare, sakit kepala, dan perdarahan yang dapat menyebabkan kematian akibat syok ${ }^{(3)}$.

Berdasarkan data World Health Organization (WHO) DHF merupakan endemik di 100 negara di Asia Pasifik, Amerika, dan Karabia dimana 50 hingga 100 juta kasus infeksi. Setiap tahunnya 500.000 kasus DHF dengan 22.000 Angka kematian. Dinegara Indonesia kasus DHF di tahun 2018 jumlah 65.602 kejadian, dengan angka kematian berjumlah 467 jiwa. Terjadi penurunan kasus dari data tahun 2017, yaitu jumlah kematian 493 jiwa dari 68.407 kasus ${ }^{(4)(5)}$.

Di Sumatera Utara tahun 2018 dari 33 Kabupaten/kota kasus tertinggi DHF adalah kota Medan sebanyak 1.490 kasus, Deli serdang 997 kasus, Kabupaten Langkat jumlah kasus 616 kasus, untuk kasus yang paling rendah terjadinya kasus DHF adalah Kabupaten/kota Mandailing Natal 0 kasus, Nias utara 2 kasus, Padang lawas utara 4 kasus $^{(6)}$.

Berdasarkan kriteria WHO DHF dapat Didiagnosa apabila, demam akut yang bersifat bifasik 2-7 hari, ada perdarahan : uji tourniquet positif ekimosis, petekia, perdarahan mukosa saluran cerna, dari hasil laboratorium trombositopenia < $100.000 \mathrm{sel} / \mathrm{mm}^{3}$.

Untuk indikasi rawat inap pasien DHF jika nilai trombosit $<100.000 \mathrm{sel} / \mathrm{mm}^{3}$ dan juga ditemukan syok dijenjang hari ke-3 hingga hari ke-7. Indikasi pasien DHF dapat pulang, tidak ada demam selama 24 jam tanpa obat, nafsu makan meningkat, terlihat perbaikan secara klinis, hematokrit stabil, dan trombosit mencapai $>50.000 \mathrm{sel} / \mathrm{mm}^{(7)}$.

Pencegahan DHF yaitu dengan melakukan: peningkatan kegiatan surveilens penyakit dan surveilens vektor, mendiagnosis dini dan melakukan pengobatan sesegera mungkin, pengobatan upaya pemberantasan vektor penular penyakit DHF. Peran masyarakat sangat dibutuhkan untuk melakukan gerakan $3 \mathrm{M}$ plus (menguras, menutup, dan mengubur) plus menabur larvasida hal tersebut bisa membantu menurunkan angka kejadian penyakit ${ }^{(5)}$

Tata cara diagnosa maupun penatalaksanaan pasien DHF sudah diketahui, namun oleh karena kemajuan ilmu kedokteran dan teknologinya yang maju, maka perubahan tempat dan waktu dapat merubah tata cara tersebut. Sehubungan dengan itu timbul pertanyaan bagaimana tata cara diagnosa dan tatalaksana dilakukan pada pasien DHF rawat inap di RSU Royal Prima. Maka itu perlu dilakukan penelitian gambaran diagnostik maupun tatalaksana penderita DHF yang rawat inap di RSU Royal Prima Medan tahun 2019.

\section{METODE}

Penelitian dengan desain studi kasus yang bersifat deskriptif dan retrospektif merupakan jenis penelitian yang dilakukan. Penelitian ini berdasarkan pada data rekam medis terkait gambaran diagnosa dan tatalaksana pasien DHF rawat inap di RSU Royal Prima tahun 2019. Penelitian ini dilakukan dibagian Rekam Medik Rumah Sakit Umum Royal Prima Medan terletak di jalan Ayahanda No. 68A, Medan, Sumatera Utara. Waktu penelitian 11 mei 2020. Banyak sampel yang diperlukan minimal berjumlah 100 data rekam medis pasien dengue hemorrhagic fever (DHF) yang dirawat diRSU Royal Prima Medan tahun 2019. Metode Pengumpulan data yang digunakan yaitu dengan cara purposive sampling berupa rekam medis yang paling lengkap datanya. Analisa data menggunakan program SPSS dan kemudian data dianalisis dengan cara deskriptif statistik distribusi proporsi dan disajikan dalam bentuk berupa narasi, tabel distribusi proporsi dan gambar (batang dan pie).

\section{HASIL DAN PEMBAHASAN}

Penelitian ini dilaksanakan demi mengetahui gambaran diganosa dan tatalaksana DHF di RSU Royal Prima Medan Tahun 2019. Banyak sampel yang digunakan sebanyak 100 sampel dengan metode penelitian desain studi kasus deskriptif retrospektif yang diambil secara purposive sampling. Hasil penelitian ialah umur termuda 4 tahun dan umur tertua 59 tahun dengan sex ratio $=56 / 44 \times 100 \%=127,2 \%$ dengan jumlah laki-laki 56 orang dan perempuan 44 orang. Dari kelompok umur terbanyak diusia 12-19 tahun (35\%) dengan jumlah laki-laki (26\%) dan jumlah perempuan (9\%). Distribusi proporsi pasien DHF yang rawat inap di RSU Royal Prima Medan Tahun 2019 dapat dilihat pada table 1. Umur yang terbanyak adalah kelompok umur 12-19 tahun (35\%) dengan banyak laki-laki (26\%) dan juga 
Jurnal Ilmiah Mahasiswa Kesehatan Masyarakat Vol. 5/No. 3/Juli 2020; Issn: 2502-731X

perempuan (9\%), umur 20-27 tahun (26\%) dengan laki -laki (10\%) dan perempuan (16\%), kelompok umur 28-35 tahun (12\%) dengan laki-laki (8\%) dan perempuan (4\%), kelompok umur 4-11 tahun (11\%) laki-laki (3\%) dan perempuan (8\%) kategori umur 36-43 tahun (8\%) jumlah laki-laki (6\%) dan perempuan (2\%), kelompok umur 44-51 tahun (7\%) dengan laki-laki (3\%) dan perempuan (4\%), kelompok umur 52-59 tahun (1\%) dengan distibusi laki-laki tidak ada dan perempuan (1\%)

Tabel 1. Distribusi Proporsi Pasien DHF Rawat Inap Berdasarkan Umur dan Jenis Kelamin yang Dirawat di RSU Royal Prima Medan Tahun 2019

\begin{tabular}{ccccccc}
\hline & \multicolumn{2}{c}{ Laki-laki } & \multicolumn{2}{c}{ Perempuan } & \multicolumn{2}{c}{ Jumlah } \\
\hline $\begin{array}{c}\text { Umur } \\
\text { (Tahun) }\end{array}$ & F & $\%$ & F & \% & F & $\%$ \\
\hline $4-11$ & 3 & 3 & 8 & 8 & 11 & 11 \\
\hline $12-19$ & 26 & 26 & 9 & 9 & 35 & 35 \\
\hline $20-27$ & 10 & 10 & 16 & 16 & 26 & 26 \\
\hline $28-35$ & 8 & 8 & 4 & 4 & 12 & 12 \\
\hline $36-43$ & 6 & 6 & 2 & 2 & 8 & 8 \\
\hline $44-51$ & 3 & 3 & 4 & 4 & 7 & 7 \\
\hline $52-59$ & 0 & 0 & 1 & 1 & 1 & 1 \\
\hline Total & $\mathbf{5 6}$ & $\mathbf{5 6}$ & $\mathbf{4 4}$ & $\mathbf{4 4}$ & $\mathbf{1 0 0}$ & $\mathbf{1 0 0}$ \\
\hline & & & & & &
\end{tabular}

Dalam teori disebut bahwa DBD sering dijumpain pada anak-anak remaja >15 tahun. Pasien DHF banyak terdapat diusia relatif muda sebab mempunyai respon imunitas yang lebih kuat dibanding orang dewasa. jika anak terinfeksi oleh virus dengue, proses immunopatologi yang terjadi lebih hebat sehingga warning sign yang muncul pada anak lebih hebat dibandingkan usia dewasa. Angka terjadi pada laki-laki lebih tinggi disebabkan karena aktivitas laki-laki lebih sering dilakukakan diluar rumah ${ }^{(8)}$

Penelitian ini hampir serupa dengan penelitian yang dilakukan oleh Sri Ayu Mulyati dkk dalam penelitiannya tentang Studi Spasial Persebaran Penyakit Demam Berdarah Dengue (DBD) diwilayah kerja Puskesmas Lepo-lepo. Menurut hasil penelitian yang telah dilakukan, didapati bahwa kasus DBD di wilayah kerja puskesmas lepo-lepo dengan jumlah kasus tertinggi pada kelompok usia produktif yaitu usia 15-23 tahun didapati total penderita sebanyak 46 orang (41.44\%). Dan kecenderungan kejadian berdasarkan jenis kelamin penyakit DBD hampir sama ${ }^{(9)}$.

Distribusi proporsi pasien DHF berdasarkan keluhan utama didapatkan hasil terbanyak adalah demam tinggi (95\%). Sesuai dengan penelitian Andi Nurul Khdijah dkk didapati distribusi keluahan utama demam tinggi $(100 \%)^{(10)}$. Distribusi proporsi pasien DHF serta keluhan tambahan kombinasi bisa dilihat pada tabel 2 .

Tabel 2. Distribusi Proporsi Pasien DHF Rawat Inap Berdasarkan

Keluhan Tambahan Kombinasi yang Dirawat di RSU Royal Prima Medan Tahun 2019

\begin{tabular}{|c|c|c|}
\hline Keluhan Tambahan Kombinasi & $\mathbf{F}$ & $\%$ \\
\hline Mual + muntah & 70 & 70 \\
\hline Mual - muntah + pegal/nyeri sendi & 12 & 12 \\
\hline $\begin{array}{l}\text { Mual - muntah +pegal/nyeri sendi + } \\
\text { sakit kepala }\end{array}$ & 8 & 8 \\
\hline $\begin{array}{l}\text { Mual - muntah + sakit kepala }+ \\
\text { nyeri ulu hati }\end{array}$ & 7 & 7 \\
\hline $\begin{array}{l}\text { Mual - muntah + sakit kepala + } \\
\text { nyeri ulu hati + pegal / nyeri sendi }\end{array}$ & 3 & 3 \\
\hline Total & 100 & 100 \\
\hline
\end{tabular}

Pada penelitian yang telah dilakukan oleh Ita Indah Agustini Mengenali Karakteristik Pasien DBD di RSUD Undata Palu, hampir serupa dengan penelitian ini. Pada penelitian yang telah dilakukan oleh Ita Indah Agustini didapati pasien DHF yang datang dengan keluhan mual-muntah sebanyak (74\%) dan pasien yang dengan keluhan sakit kepala (18\%), dan nyeri ulu hati (5\%). Sementara pada penelitian ini didapati pasien dengan keluhan mualmuntah sebanyak (70\%) dan pasien yang dengan keluhan tambahan pegal/nyeri sendi (23\%), sakit kepala $(10 \%)$, dan nyeri ulu hati $(10 \%)^{(11)}$.

Distribusi proporsi pasien DHF berdasarkan hasil pemeriksaan kadar trombosit didapati responden yang mengalami penurunan kadar trombosit (87\%) dan normal sebanyak (13\%) dan $\mathrm{Ht}$ $>20 \%$ (73\%). Sesuai dengan teori yang menyatakan bahwa saat dilakukan pemeriksaan seringkali dijumpain kadar trombosit yang rendah dan peningkatan hematokrit, hal ini sesuai dengan penelitian ini. Jumlah trombosit di bawah 100.000/ul ditemukan di antara hari ke-3 sampai ke-7 sakit. Peningkatan hematokrit adalah tanda bahwa telah terjadi kebocoran plasma, pada derajat ringan juga terjadi kebocoran plasma meskipun tidak sehebat sewaktu keadaan renjatan ${ }^{(12)}$. Penelitian ini sesuai dengan penelitian yang telah dilaksanakan oleh Amrina Rasyada dkk, didapatkan hasil trombosit krang dari $100.000 \mathrm{sel} / \mathrm{mm}^{3}$ sebesar $(86,6 \%)$ dan pasien dengan trombosit $>100.000$ $\mathrm{sel} / \mathrm{mm}^{3}(13,4 \%)^{(13)}$.

Distribusi proporsi pasien DHF berdasarkan Hasil Pemeriksaan penunjang tes imunologi yang terbanyak pasien mengalami infeksi sekunder 
Jurnal Ilmiah Mahasiswa Kesehatan Masyarakat Vol. 5/No. 3/Juli 2020; Issn: 2502-731X

(77\%), dan tidak diperiksa sebanyak (23\%). Penelitian ini mirip dengan dengan yang dilakukan Ni Nyoman Lidya Trisnadewi dkk, Pola Serologi IgG dan IgM pada Infeksi Demam Berdarah Dengue di Rumah Sakit Umum Pusat Sanglah, Denpasar, Bali dengan distribusi infeksi sekunnder lebih banyak $(92 \%)^{(14)}$.

Distribusi proporsi pasien DHF berdasarkan penatalaksanaan medikamentosa didapati Paracetamol (100\%), diikuti Antiemetik (95\%), dan Proton Pump Inhibitor (PPI) (93\%), kemudian vitamin B-complex (67\%). Distribusi proporsi berdasarkan penatalaksanaan dapat dilihat pada gambar 1.

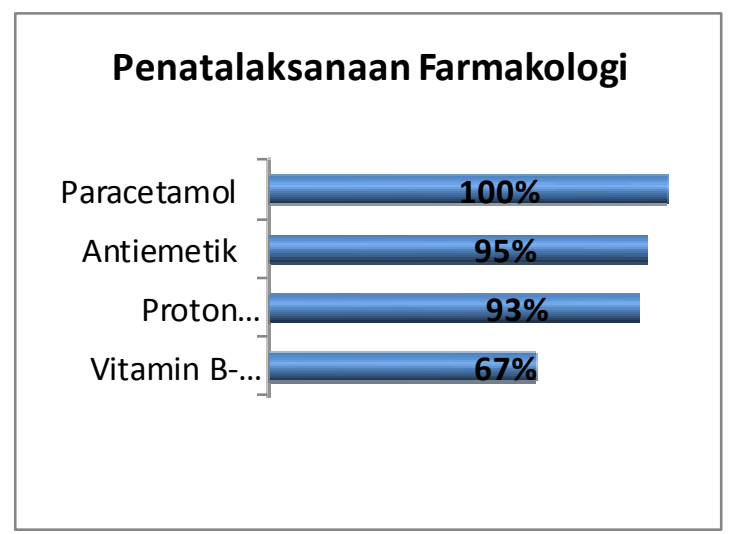

Gambar 1. Diagram Bar Distribusi Proporsi pasien DHF Berdasarkan Penatalaksanaan Medikamentosa yang Dirawat di RSU Royal Prima Tahun 2019

Distribusi proporsi pasien DHF berdasarkan lama rawatan yang tersingkat 2 hari dan terlama 6 hari, dan terbanyak 3 hari (35\%). Bisa dilihat pada tabel 3.

Tabel 3. Distribusi Proporsi Pasien DHF Rawat Inap Berdasarkan Lama Rawatan yang Dirawat di RSU Royal Prima Medan Tahun 2019

\begin{tabular}{ccc}
\hline Lama Rawatan & F & \% \\
\hline 2 hari & 4 & 4 \\
\hline 3 hari & 35 & 35 \\
\hline 4 hari & 26 & 26 \\
\hline 5 hari & 20 & 20 \\
\hline 6 hari & 15 & 15 \\
\hline
\end{tabular}

Banyak faktor yang berkontribusi terhadap terjadinya DHF diantaranya adalah usia, tingkat keparahan, faktor tersebut juga mempengaruhi terhadap lamanya pasien rawat inap DHF di rumah sakit. Hasil penelitan ini sedikit berbeda dengan penelitian yang dilakukan oleh I Wayan Adi Pranata, dkk Gambaran Pola Penatalaksanaan DBD di RSUD Kabupaten Buleleng. Menyebutkan bahwa lama rawatan sebagian besar pasien DHF adalah 4 hari.
Distribusi proporsi berdasarkan kodisi pasien sewaktu pulang didapati, sembuh klinis (83\%), diikuti berobat jalan (10\%), dan Pulang Atas Permintaan Sendiri (PAPS) (7\%). Pada penelitian yang dilakukan tidak terdapat kondisi sewaktu pulang dengan meninggal dunia. Dapat dilihat pada gambar 2.

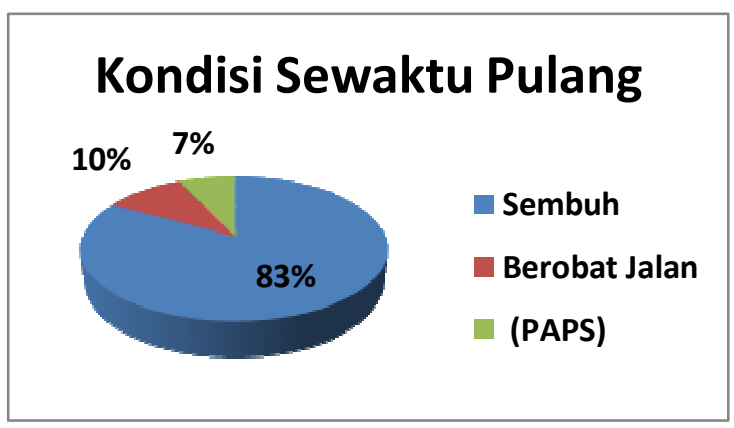

Gambar 2. Diagram Pie Distribusi Proporsi Pasien DHF Rawat Inap Berdasarkan Kondisi Sewaktu Pulang yang Dirawat di RSU Royal Prima Medan Tahun 2019

\section{PENUTUP}

Berdasarkan penelitian yang dilakukan, disimpulkan bahwa distribusi proporsi pasien DHF di RSU Royal Prima Medan Tahun 2019 menurut umur, jenis kelamin, keluhan utama, keluhan tambahan, pemeriksaan fisik, pemeriksaan penunjang, tatalaksana famakologi maupun non farmakologi, lama rawatan dan kondisi sewaktu pulang, sebagian besar penderita DHF berada pada rentang umur 12-19 tahun, berjenis kelamin laki-laki (26\%), dan berdasarkan keluhan utama yang terbanyak adalah demam tinggi (95\%), keluhan tambahan kombinasi yang tebanyak mual-muntah (70\%) dan berdasarkan hasil pemeriksaan pasien dengan dengan keadaan trombositopenia (87\%) dan $\mathrm{Ht}>20 \%$ (73\%) serta pemeriksan serologi IgG/IgM dengan hasil infeksi sekunder (100\%). Dan tatalaksana tersering diberikan paracetamol + antiemetic + proton pump inhibitor + vitamin (60\%). Berdasarkan lama rawatan terbanyak 3 hari (35\%), tersingkat 2 hari dan waktu terlama 6 hari, dan kondisi sewaktu pulang pada pasien DHF ialah sembuh (83\%).

Maka dari itu perlu dilakukan penelitian lebih lanjut demi mengetahui faktor-faktor yang berkaitan dengan penyebab terjadinya DHF untuk laki laki kelompok umur 12-19 tahun dan perempuan kelompok umur 20-27 tahun.

\section{DAFTAR PUSTAKA}

1. Pranata IWA, Artini IGA. Gambaran Pola Penatalaksanaan Demam Berdarah Dengue 
Jurnal Ilmiah Mahasiswa Kesehatan Masyarakat Vol. 5/No. 3/Juli 2020; Issn: 2502-731X

(DBD) Pada Anak di Instalasi Rawat Inap Rumah Sakit Umum Daerah Kabupaten Buleleng Tahun 2013. E-Jurnal Med Udayana. 2017;6(5):21-7.

2. Nuryati E. Analisis Spasial Kejadian Demam Berdarah Dengue Di Kota Bandar Lampung Tahun 2006-2008. J Ilm Kesehat. 2012;1(2).

3. Mayasari $R$, Sitorus $H$, Salim M, Oktavia $S$, Supranelfy $Y$, Wurisastuti T. Karakteristik Pasien Demam Berdarah Dengue pada Instalasi Rawat Inap RSUD Kota Prabumulih Periode Januari-Mei 2016. Media Penelit dan Pengemb Kesehat. 2019;29(1):39-50.

4. Candra A. Dengue Hemorrhagic Fever Epidemiology, Pathogenesis, and Its Transmission Risk Factors. Aspirator J Vector Borne Dis Stud. 2010;2(2):110-9.

5. Kemenkes RI. Profil Kesehatan Indonesia 2018..[Indonesia Health Profile 2018] [Internet]. 2019. 207 p. Available from: http://www.depkes.go.id/resources/download /pusdatin/profil-kesehatan-indonesia/Datadan-Informasi_Profil-Kesehatan-Indonesia2018.pdf

6. Syukur $P$, Yang $T$, Esa $M$, Kesehatan $P$, Sumatera $P$, Tahun $U$, et al. profil kesehatan sumut 2018.

7. Hermiyanty, Wandira Ayu Bertin DS. dengue hemorrhagic fever. J Chem Inf Model. 2017;8(9):1-58.

8. Soegijanto S....Demam Berdarah Dengue Edisi 2. Surabaya Airlangga Univ Press Hal. 2006;

9. Mulyati S, Majid R, Ibrahim K. Studi Spasial Persebaran Penyakit Demam Berdarah Dengue (Dbd) di Wilayah Kerja Puskesmas Lepo-lepo Kota Kendari Tahun 2013-2016...J Ilm Mhs Kesehat Masy Unsyiah. 2016;1(3):183281.

10. Khadijah AN,,,Utama IMGDLU. Gambaran gejala klinis demam berdarah dengue pada anak di RSUP Sanglah, Denpasar selama bulan Januari-Desember 2013. E-Jurnal Med. 2017;6(11):92-7.

11. Agustini II, Bangkele EY, Salman M, Munir MA. KARAKTERISTIK PASIEN DEMAM BERDARAH DENGUE (DBD) PADA RUANG RAWAT INAP ANAK DI RSUD UNDATA PALU TAHUN 2017. Med Tadulako. 2018;5(3).

12. Soedarmo S. Infeksi virus dengue. Buku Ajar Infeksi dan Pediatr. 2008;

13. Rasyada A, Nasrul E,,,Edward Z. Hubungan Nilai Hematokrit Terhadap Jumlah Trombosit pada Penderita Demam Berdarah Dengue. J Kesehat Andalas. 2014;3(3):343-7.

14. Trisnadewi NNL, Wande IN...Pola Serologi IgM dan IgG Pada Infeksi Demam Berdarah Dengue
(BDB) Di Rumah Sakit Umum Pusat Sanglah, Denpasar, Bali Bulan Agustus Sampai September 2014. E-Junal Med. 2016;5(8):1-5. 